\title{
Dolfspind ologie
}

\section{Das Seelenleben im Spiegel der Spradje}

\author{
Don
}

Dr. RudoIf KIeinpauI

nun leht iht, weld ein nt丸htswürolges

Ding ihr aus mir maht! Gamlet

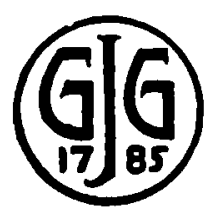

Berlin und Seipzig

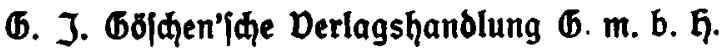


Alle Rehte, befonbers bas îtberlebungsteht. pon ber Derlagshanolung vorbehalten.

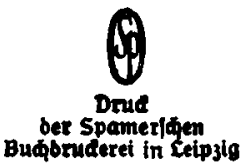

